Travaux du Muséum National d'Histoire Naturelle «Grigore Antipa»
Vol. 61 (1)

pp. $13-17$

\title{
Revision of Anthaxia salicis Species Complex in Romania, with the First Record of Anthaxia suzannae (Coleoptera: Buprestidae)
}

\author{
Adrian RUICĂNESCU ${ }^{1, *}$, Gabriela CUZEPAN BEBEȘELEA², \\ Andreea-Cătălina DRĂGHICI ${ }^{3}$
}

\begin{abstract}
${ }^{1}$ National Institute of Research and Development for Biological Sciences, Branch of Cluj-Napoca, 48 Republicii, 400015 Cluj-Napoca, Romania

${ }^{2}$ Brukenthal National Museum, The Natural History section, 1 Cetății, 550169 Sibiu, Romania

3"Grigore Antipa" National Museum of Natural History, Entomology, 1 Kiseleff, 011341 Bucharest, Romania

"corresponding author, e-mail: a.ruicanescu@gmail.com
\end{abstract}

Received: February 12, 2018; Accepted: April 18, 2018; Available online: May 10, 2018; Printed: June 30, 2018

\begin{abstract}
One specimen of Anthaxia (Anthaxia) suzannae Théry, 1942 was collected on a meadow, near Cluj-Napoca, Romania. Although this species is widely distributed in Europe, this is the first record of its presence in Romania. A short description of the species, and some considerations about the biology and zoogeography are given.
\end{abstract}

Key words: Anthaxia salicis complex, Anthaxia suzannae, Buprestidae, new record, Romania.

\section{INTRODUCTION}

One small specimen of Anthaxia salicis complex has been collected in "Pădurea de stejar pufos de la Hoia" Site of Community Importance (ROSCI0146) close to ClujNapoca, on 9.V.2015. After a detailed examination of the specimen, it was identified as Anthaxia (Anthaxia) suzannae Théry, 1942, the first record of this species in the Romanian fauna ${ }^{1}$. In Romania, only two species of the Anthaxia salicis complex are known: Anthaxia (Anthaxia) salicis (Fabricius, 1777) and A. (A.) semicuprea Küster, 1851 (Ruicănescu, 2013; Panin et al., 2015). The species belonging to the Anthaxia (Anthaxia) salicis (Fabricius, 1777) species complex are characterized by specific pronotal microsculpture, consisting of fine concentric ripples on its disc, reminding of a heart design (Fig. 1). This particular structure of the pronotum may be a convergence rather than a close relation. We don't have any information on the utility of this structure for the insects, but it also appears in the Anthaxia (Anthaxia) plicata (Kiesenwetter, 1859) species group, the Anthaxia (Melanthaxia) morio (Fabricius, 1792) and recently, the newly described species complexes Anthaxia (Anthaxia) midas Kiesenwetter, 1857 and Anthaxia (Anthaxia) brevis Gory \& Laporte, 1839 (Baiocchi \& Magnani, 2018).

The members of Anthaxia (Anthaxia) salicis (Fabricius, 1777) species complex can be recognised from the middle-sized body (3-6 $\mathrm{mm}$ length), head and pronotum usually green or blueish, with or without two dark blue markings, but without touching the other marginal marks. The scutellar spot is triangular or semi-circular; the entire anterior third of the elytra, including scutellum, is green or blueish, the rest of elytra

${ }^{1}$ A. suzannae is mentioned from Romania in the Catalogue of Palearctic Coleoptera (Löbl \& Löbl, 2016 - cited from Löbl \& Smetana, 2006), but there is no published paper indicating the locality or the collecting period. 


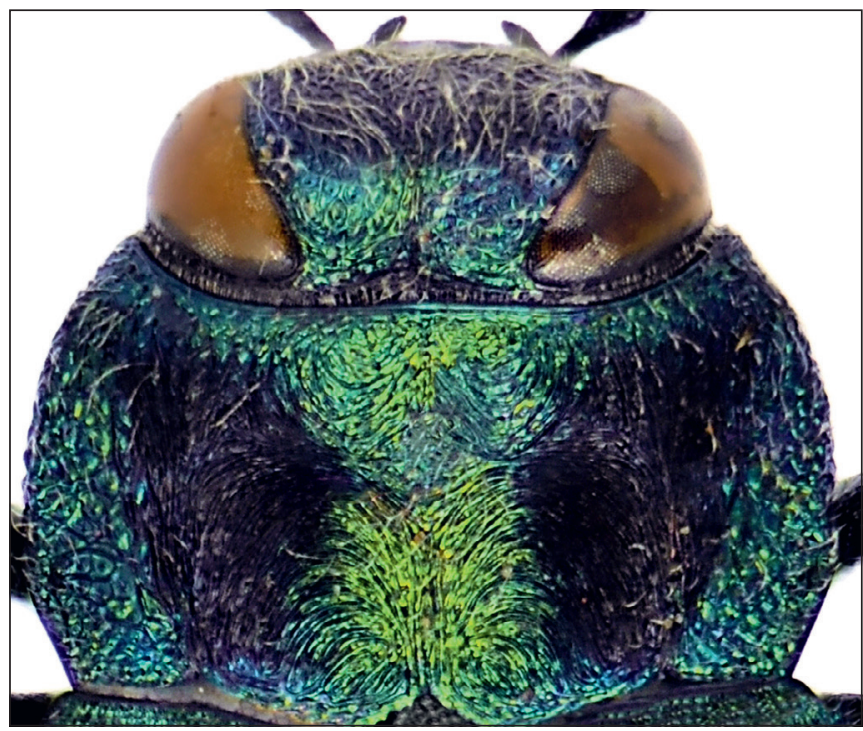

Fig. 1 - The concentric rippled microstructure of the pronotum of Anthaxia salicis (photo: A. Ruicănescu).

being copper-red with or without a posterior darker nebulous spot, but never a well outlined dark pattern.

The pronotum structure displays two distinct concentric ripple areas: a basal, large one, anterior to the scutellum, and another, smaller one, behind the anterior margin, in contrast to the Anthaxia (Anthaxia) midas Kiesenwetter, 1857 species complex, where there is an altered cell-based structure and Anthaxia (Anthaxia) brevis Gory \& Laporte, 1839 species complex, where the ripples form an "X" marking (Baiocchi \& Magnani, 2018).

\section{MATERIALS AND METHODS}

The above-mentioned specimen was collected from a meadow with Crataegus monogyna and Rosa canina bushes. No other specimen was found in that area during the next years.

We checked and revised all the Anthaxia salicis material stored in the collections of the largest museums of natural history in Romania, "Grigore Antipa" National Museum of Natural History, Bucharest (MGAB) and Brukenthal National Museum, the Museum of Natural History, Sibiu (BNM) as well as in Adrian Ruicănescu's collection. 159 specimens of the Anthaxia salicis complex, from the collection of MGAB, were examined: 150 specimens of $A$. salicis, eight specimens of $A$. semicuprea and one of $A$. suzannae. 86 specimens were examined from the collections of BNM, identified as Anthaxia salicis (82 specimens), A. semicuprea (two specimens) and A. suzannae (two specimens). Photographs of every species are given. Additionally, 37 specimens were examined in Adrian Ruicănescu's collection; eight specimens of Anthaxia semicuprea, three specimens of $A$. suzannae (two specimens from Bulgaria, used just for reference) and 26 specimens of $A$. salicis. 

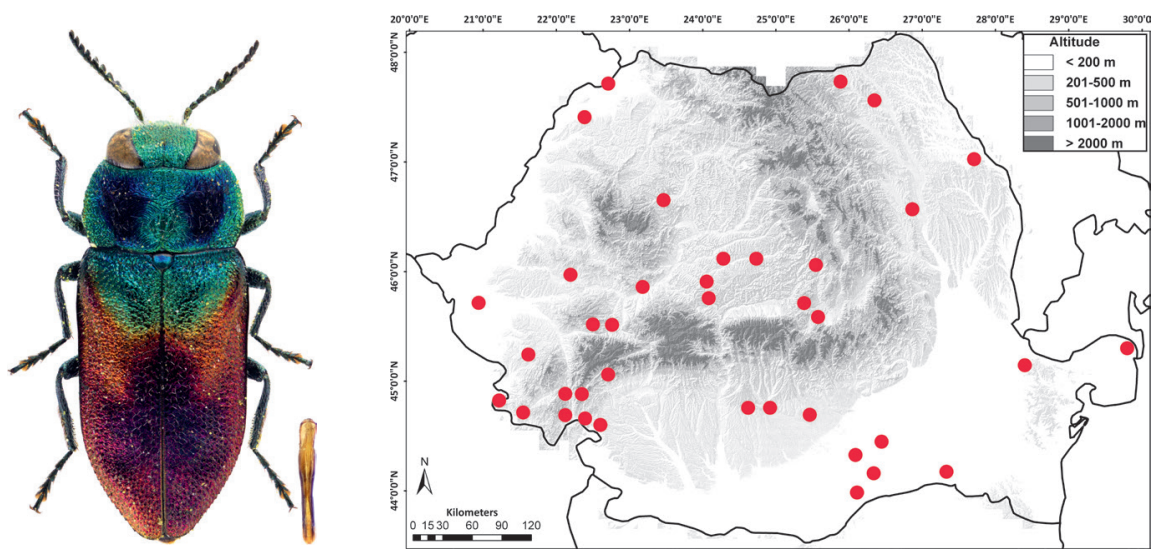

Fig. 2 -Anthaxia salicis (F.) and its distribution in Romania (photo: A. Ruicănescu).
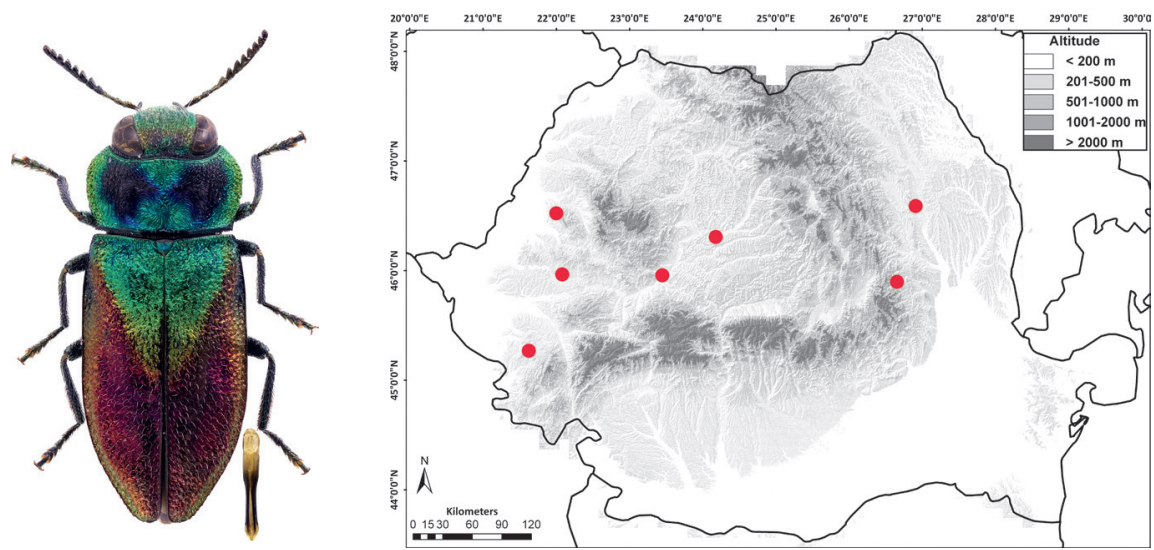

Fig. 3 -Anthaxia semicuprea Kust and its distribution in Romania (photo: A. Ruicănescu).
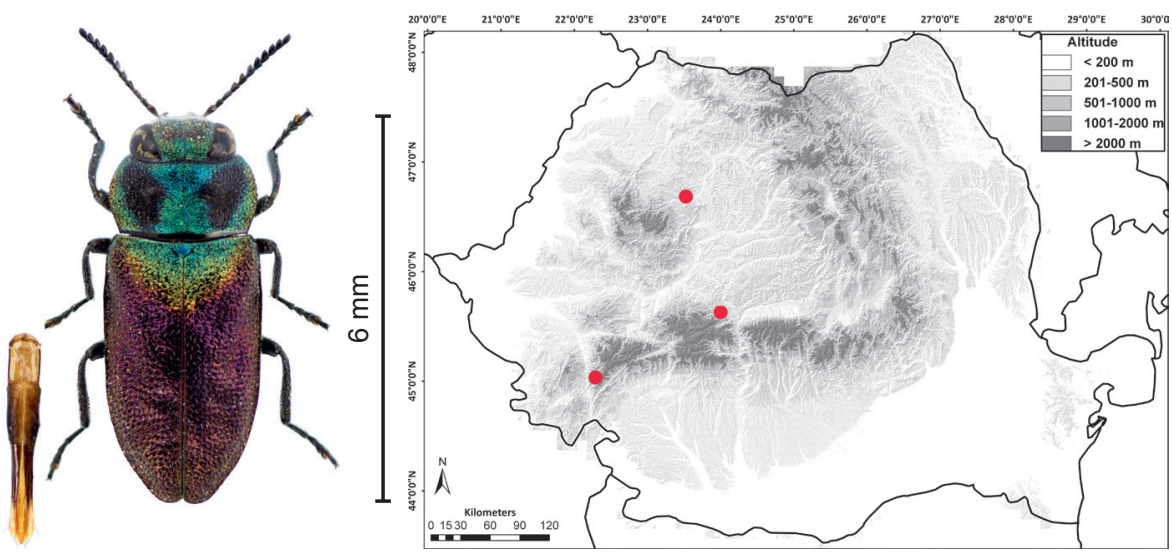

Fig. 4 - Anthaxia suzannae Théry and its distribution in Romania (photo: A. Ruicănescu). 


\section{RESULTS AND DISCUSSIONS}

To date, two species are known in the insect fauna of Romania: Anthaxia (Anthaxia) salicis and Anthaxia (Anthaxia) semicuprea. The third species, belonging to this complex, was recently recorded in Romania for the first time: Anthaxia (Anthaxia) suzannae Théry, 1942, found and identified by Adrian Ruicănescu in "Pădurea de stejar pufos de la Hoia-Baciu" protected area, near Cluj-Napoca, on 9.V.2015 (leg/coll. A. Ruicănescu). Based on this record, we have checked if other specimens were collected in Romania, so all material belonging to the Anthaxia salicis complex, preserved in the collections of the two natural history museums of Romania were analysed.

As a result of this study, three other specimens of Anthaxia suzannae were found: Dumbrava Sibiului, V.1924, coll. Worell (coll. BNM); Băile Herculane, VI.1929, coll. Worell (coll. BNM); Băile Herculane, 18.V.1965, leg. Nicolae Săvulescu (coll. MGAB), all erroneously identified as Anthaxia croesus, A. salicis or A. semicuprea.

The Anthaxia salicis complex consists of 20 species, distributed in Europe (except the Scandinavian Peninsula and the British Islands), from southern Central European Russia, Iran, surroundings of the Mediterranean Sea to the Iberian Peninsula, and Algeria and Morocco.

Nowadays, three species are known from Romania: Anthaxia salicis, A. semicuprea and A. suzannae.

Anthaxia (Anthaxia) salicis salicis (Fabricius, 1777) is the most common species, being distributed everywhere in Romania, under $800 \mathrm{~m}$ altitude (fig. 2). It is a Maghrebo-Sibero-European element, with a vast distribution, developing in Acer obtusatum, Castanea sativa, Quercus pubescens, Q. sp., Salix sp., Malus sp., Pyrus sp., Prunus sp., Sorbus sp., Cydonia oblonga The adults can be found on flowers (Ruicănescu, 2013; Sakalian, 2003). Anthaxia (Anthaxia) semicuprea Kuster, 1851 is much rarer, distributed in the hilly or lower mountain areas (fig. 3). This species is a Maghrebo-Sibero-European element (Ruicănescu, 2013), with also a vast distribution. It develops in Acer pseudoplatanus, Crataegus sp., Cydonia oblonga, Malus domestica, Pyrus communis, Quercus cerris, Sorbus domestica, Cornus mas, Ulmus sp. The adults occur on yellow flowers (Ruicănescu, 2013; Sakalian, 2003). Anthaxia (Anthaxia) suzannae Théry, 1942 is known only in Banat and in Transylvania now (Fig. 4). Globally, it is distributed on a vast territory (Austria, Bosnia-Herzegovina, Bulgaria, Croatia, Czech Republic, France, Germany, Hungary, Italy, Macedonia, Montenegro,
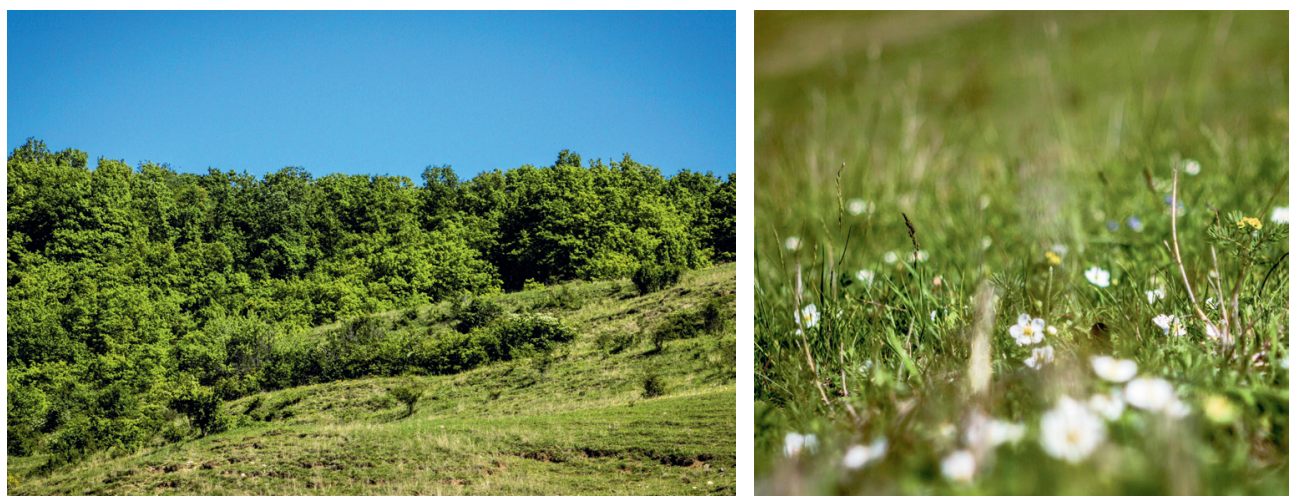

Fig. 5 - The habitat and micro biotope of $A$. suzannae at Pădurea de stejar pufos de la Hoia-Baciu (photo: A. Ruicănescu). 
Serbia, Slovakia, Spain, Switzerland, Turkey, Ukraine) (Löbl \& Löbl, 2016). Despite its wide distribution, it is a rare species, sporadically found in all countries where it was recorded. It develops in Malus domestica, Pirus communis, Sorbus sp., Prunus $s p$., Crataegus sp. (www.anthaxia.eu). The adults can be found on flowers. The senior author found the specimen on flowers of Fragaria vesca in a meadow with scarce shrubs of Crataegus monogyna and Rosa canina (Fig. 5).

\section{ACKNOWLEDGEMENTS}

This study was funded by the Romanian Ministry of Education within the research program PN 09-360201/2009 and by the Ministry of Research and Innovation within the National Research Program 30N/18180301, Biodivers 2.

\section{REFERENCES}

BAIOCCHI, D., G. MAGNANI (2018) A revision of the Anthaxia (Anthaxia) midas Kiesenwetter, 1857 species-group (Coleoptera: Buprestidae: Anthaxiini). Zootaxa 4370 (3): 201-254.

CURLETTI, G. (1994) I Buprestidi d'Italia. Catalogo tassonomico, sinonimico, biologico, geonemico. Monografie di "Natura Bresciana", 19: 1-318. (in Italian)

LÖBL, I., D. LÔBL (2016) Catalogue of Palaearctic Coleoptera 3, updated and revised, pp.1-690.

MÜHLE, H., P. BRANDL, M. NIEHUIS (2000) Catalogus Faunae Graeciae Coleoptera: Buprestidae. Georg Rößle, Augsburg. 254 pp.

PANIN, S., N. SĂVULESCU, A. RUICANESCU (2015) Coleoptera-Buprestidae. In: Fauna României, Insecta, vol. X, fasc. 7, Academia Română, București. (in Romanian)

RUICĂNESCU, A. (2013) The Jewel Beetles of Romania (Coleoptera: Buprestidae), Sofia: Pensoft Publishers.

RUICĂNESCU, A., R. SERAFIM (1996) Specii noi sau puţin cunoscute de Buprestoidea pentru fauna României din colecţia Dr. N. Săvulescu de la Muzeul de Istorie Naturală "Grigore Antipa" din București (Coleoptera: Buprestoidea). Entomologica romanica, 1: 69-76. (in Romanian)

*** Anthaxia from Western Palearctic and Middle East Region (http://www.anthaxia.eu) 